\title{
TRINITARIAN DOXOLOGY: REASSESSING JOHN OWEN'S CONTRIBUTION TO REFORMED ORTHODOX TRINITARIAN THEOLOGY,
}

\section{Ryan M McGraw}

Research Associate, University of the Free State Associate Professor of Systematic Theology, Greenville Presbyterian Theological Seminary ryan.m.mcgraw@gmail.com

\section{ABSTRACT}

Reformed orthodox theologian Gisbertus Voetius (1589-1676) referred to the doctrine of the Trinity as 'the foundation of fundamentals'. Richard Muller notes that if any dogma comes close to achieving such status, it is the doctrine of the Trinity. It is thus surprising that most modern treatments of trinitarian theology assume that sixteenth and seventeenth century Reformed orthodoxy had virtually nothing to contribute to this vital doctrine. The recent Cambridge Companion to the Trinity and the Oxford Handbook of the Trinity both reflect this assumption. This article addresses how Reformed authors tried to harmonise the historical doctrine of the Trinity with their principle of sola scriptura. It does not treat positive developments or applications of the doctrine. The void left in the secondary literature has not adequately probed the bold claims of Voetius or the scholarly reflections of Muller. John Owen (1616-1683) is a growing exception to this trend. Both historians and theologians are starting to recognise his significance as a theologian in general and a trinitarian theologian in particular, but they often stop short of observing how he intertwined his trinitarian theology and piety throughout his writings. This article will reassess Owen's contribution to Reformed trinitarian theology in two major segments. The first does so by critiquing two recent treatments of his work. The remaining material explores the

1 This article appeared first as a single article in Westminster Theological Journal. Used with permission.

\section{UNISA $\cong$}

Studia Historiae Ecclesiasticae Volume 41 | Number 2 | 2015 pp. $38-68$
DOI: http://dx.doi.org/10.17159/2412-4265/2015/92 Print ISSN 1017-0499 | Online 2412-4265 (C) 2015. Studia Historiae Ecclesiasticae 
theological foundations of Owen's trinitarian doxology followed by the theological and practical conclusions that he drew from his theology in relation to Scripture, spiritual affections, covenant theology, and ecclesiology. Owen illustrates that one of the primary contributions of Reformed orthodoxy to trinitarian theology lies in its integration into Reformed soteriology and piety. This article reassesses Owen's contribution to trinitarian theology and provides clues for scholars to trace the significance of the Reformed contribution to trinitarian theology in other authors within that tradition.

Keywords: Trinitarian doxology; John Owen; Reformed orthodoxy; trinitarian theology; Protestant scholasticism; Socinianism

\section{INTRODUCTION}

Reformed orthodox theologian Gisbertus Voetius (1589-1676) referred to the doctrine of the Trinity as 'the foundation of fundamentals'. ${ }^{2}$ While Richard Muller dissuades scholars from searching for a 'central dogma' in historic Reformed theology, ${ }^{3}$ he notes that if any dogma comes close to achieving such status, it is the doctrine of the Trinity. ${ }^{4}$ In light of this fact, it is somewhat surprising that most modern treatments of trinitarian theology assume that sixteenth and seventeenth century Reformed orthodoxy had virtually nothing to contribute to this vital doctrine. ${ }^{5}$

The recent Cambridge Companion to the Trinity and the Oxford Handbook of the Trinity both reflect this assumption. ${ }^{6}$ The Cambridge volume leaps four centuries from John Calvin (1509-1564) to Karl Barth, implying that little of consequence appeared in between. The Oxford Handbook devotes one out of 43 chapters to the Reformed construction of the Trinity. However, this article addresses how Reformed authors tried to harmonise the historical doctrine of the Trinity with their principle of

2 'fundamentum fundamenti.' Gisperti Voetii, Selectarum Disputationum Theologicarum, Pars Prima (Utrecht, 1648), 1: 472. See Richard A. Muller, Post Reformation Reformed Dogmatics, 1 for 'fundamental articles'.

3 Richard A Muller, Christ and the Decree: Christology and Predestination in Reformed Theology from Calvin to Perkins (Grand Rapids, Mich.: Baker Academic, 2008); Michael A.G Haykin and Mark Jones, eds., Drawn into Controversie: Reformed Theological Diversity and Debates Within Seventeenth-Century British Puritanism, vol. 17, Reformed Historical Theology (Göttingen; Oakville, Conn.: Vandenhoeck \& Ruprecht, 2011), chapter 1.

4 Richard A Muller, Post-Reformation Reformed Dogmatics: The Rise and Development of Reformed Orthodoxy, Ca. 1520 to Ca. 1725, 4 vols., 2nd ed. (Grand Rapids, Mich.: Baker Academics, 2003), 4.

5 Robert Letham, The Holy Trinity: In Scripture, History, Theology, and Worship (Phillipsburg, NJ: P \& R Pub., 2004), 1-3.

6 Peter C Phan, The Cambridge Companion to the Trinity (Cambridge; New York: Cambridge University Press, 2011); Gilles Emery and Matthew Levering, eds., The Oxford Handbook of the Trinity (Oxford; New York: Oxford University Press, 2011). 
sola scriptura. ${ }^{7}$ It does not treat positive developments or applications of the doctrine. Calvin has received significant scholarly attention, but predominantly in relation to his construction of the doctrine rather than to his use of it or its influence on his system of theology. ${ }^{8}$ The void left in the secondary literature has not adequately probed the bold claims of Voetius or the scholarly reflections of Muller. ${ }^{9}$

John Owen (1616-1683) is a growing exception to this trend. Both historians and theologians are starting to recognise his significance as a theologian in general and a trinitarian theologian in particular. Even the Oxford Handbook of the Trinity, in spite of bypassing Reformed orthodoxy, includes scattered references to Owen. ${ }^{10}$ While such treatments have contributed much to understanding the trinitarian structure of Owen's theology and piety, they often stop short of observing how he intertwined his trinitarian theology and piety throughout his writings. The lens through which he did this was the theme of public worship.

Owen regarded public worship as the highest expression of communion with God as triune. The connection that he drew between trinitarian piety and public worship illustrates how he integrated his trinitarian theology into his entire system of theology. This article will reassess Owen's contribution to Reformed trinitarian theology in two major segments. The first does so by critiquing two recent treatments of his work. The remaining material explores the theological foundations of Owen's trinitarian doxology followed by the theological and practical conclusions that he drew from his theology in relation to Scripture, spiritual affections, covenant theology, and ecclesiology. Owen illustrates that one of the primary contributions of Reformed orthodoxy to trinitarian theology lies in its integration into Reformed soteriology and piety. This article reassesses Owen's contribution to trinitarian theology and provides clues for scholars to trace the significance of the Reformed contribution to trinitarian theology in other authors within that tradition. ${ }^{11}$

\section{IDENTIFYING THE PROBLEM: TWO RECENT TREATMENTS OF OWEN'S TRINITARIANISM}

The significance of Owen's contribution to Reformed orthodox trinitarian theology is illustrated through interacting critically with two recent treatments of his thought. The first is Robert Letham's essay on Owen's Trinitarianism. The other is Paul Lim's chapter on Owen and Francis Cheynell's (1608-1665) practical Trinitarianism in

7 Scott R. Swain, 'The Trinity in the Reformers,' Oxford Handbook of the Trinity, 227-239.

8 For a notable example, see Brannon Ellis, Calvin, Classical Trinitarianism, and the Aseity of the Son (Oxford: Oxford University Press, 2012).

9 Muller notes that Reformed trinitarian theology is a neglected field. He suggests that the primary contribution of Reformed authors to this subject was exegetical. Muller, PRRD, 4: 24-25.

10 Emery and Levering, Oxford Handbook of the Trinity, 246, 506-509. Drawn into Controversie, cited above, includes Owen in nine of twelve chapters.

11 As such, it is not merely a restatement of the material from my Heavenly Directory. 
his recent work on Socinianism. While both studies are valuable, Letham appears to import modern trinitarian questions into his historical analysis, while Lim diminishes the distinctiveness of Owen's practical use of the doctrine. Both of these approaches illustrate different reasons why Owen's practical use of the Trinity has been partially underdeveloped and why contemporary authors assume that Reformed orthodoxy contributes little to trinitarian theology. This analysis sets the backdrop for the analysis below of how he intertwined the Trinity and public worship into his theological system.

\section{Asking the wrong question of the wrong century: Robert Letham ${ }^{12}$}

One of the reasons why some contemporary authors likely have missed the contribution of Reformed orthodoxy to trinitarian theology is that they ask different questions than those that occupied Reformed authors. This is evident in Robert Letham's article in the recent Ashgate Research Companion to John Owen's Theology. ${ }^{13}$

Letham asks whether Owen's trinitarian emphases have Eastern or Western tendencies. He argues that Owen's views on matters such as the fililoque clause were Western, but that his stress on distinct communion with the Divine Persons was Eastern in tone. ${ }^{14}$ In Letham's other works on the Trinity, he often gives readers the impression that Western trinitarians are the 'bad guys'. ${ }^{15}$ This essay is no exception. ${ }^{16}$ Citing an earlier publication, he notes: 'Owen is not so much an innovator as a brilliant synthesizer. ${ }^{17}$ The synthesis that he has in mind is between Western emphases on the unity of God and Eastern emphases on the Divine Persons. He adds: '[Owen's] focus on the three persons was and is missing from the West in general'. ${ }^{18}$

Letham does not sufficiently base his claims on seventeenth century evidence, by comparing or contrasting Owen to his contemporaries. By contrast, Richard Muller argues that it is impossible to classify Reformed Trinitarianism either as Eastern or

12 This material is modified from, Ryan M. McGraw, 'The Rising Prominence of John Owen: A Review Article of The Ashgate Research Companion to John Owen's Theology,' Mid America Journal of Theology, 2013.

13 Robert Letham, 'John Owen's Doctrine of the Trinity in its Catholic Context,' Ashgate Companion to Owen's Theology, 185-198.

14 Letham, 'John Owen's Doctrine of the Trinity in its Catholic Context,' 186, 191.

15 For example, throughout his work, The Holy Trinity, and in Robert Letham, 'John Owen's Doctrine of the Trinity and its Significance for Today,' in Where Reason Fails: Papers Read at the 2006 Westminster Conference (Stoke on Trent, UK: Tentmaker Publications, 2006), 10-20.

16 Letham, 'John Owen's Doctrine of the Trinity in its Catholic Context,' 188, for example.

17 Letham, 'John Owen's Doctrine of the Trinity in its Catholic Context,' 190. Cited from Letham, 'John Owen's Doctrine of the Trinity and its Significance for Today,' 11.

18 Letham, 'John Owen's Doctrine of the Trinity in its Catholic Context,' 196. The recent Oxford Handbook of the Trinity, assumes that such assertions have not been taken seriously in scholarly circles for several decades. Oxford Handbook of the Trinity, 123. 
Western. ${ }^{19}$ Showing similarities between Owen and Eastern authors on emphasising the Divine Persons means less if we find that other Western authors expressed similar emphases for different reasons. Owen is distinctive among most English writers in terms of trinitarian piety. However, he shows affinity with Dutch authors such as Voetius and Hoornbeeck (1617-1666), both of whom he cited periodically. ${ }^{20}$ Such authors developed a devotional emphasis on the Divine Persons in response to Arminianism because Arminians denied that the Trinity was a fundamental article of the faith because it had no practical value. ${ }^{21}$

While Owen was less directly concerned with Arminian views of the Trinity than these men were, it is more plausible that his emphasis on the Divine Persons stems more from continental influence than from Eastern theology. One historian warns against relying too much on English books in studying English Reformed theology following the advent of Early English Books Online..$^{22}$ Continental authors produced trinitarian emphases that were less common in an English context due to differing theological concerns. This is not to say that Eastern emphasis was not present, but the evidence that Letham produces arises from contemporary questions rather than from seventeenth century literature. Moreover, he overlooks Muller's defence of Reformed orthodoxy against the charge of abstracting the divine essence and attributes from the Trinity. ${ }^{23}$ Muller argues that the tables of contents of dogmatic works are not reliable guides to discern the relative importance of the divine attributes and the Divine Persons in these works. This is precisely the mistake that Letham makes in this essay. ${ }^{24}$

Exploring the broader context of seventeenth-century Western Trinitarianism more fully might reveal that the question of Eastern versus Western Trinitarianism was not on the Reformed horizon ${ }^{25}$ - at least not with respect to every Reformed

19 Muller, PRRD, 4: 72.

20 For example, John Owen, Theologoumena Pantodapa, Sive, De Natura, Ortu Progressu, Et Studio Verce Theologice, Libri Sex Quibus Etiam Origines \& Processus Veri \& Falsi Cultus Religiosi, Casus \& Instaurationes Ecclesice Illustiores Ab Ipsis Rerum Primordiis, Enarrantur ... (Oxoniæ: Excudebat Hen. Hall ... impensis Tho. Robinson ..., 1661), 522 (Voetius) and 519 (Hoornbeeck).

21 See Gisperti Voetii, Selectarum Disputationum Theologicarum, Pars Prima (Utrecht, 1648), 1: 472, who called the Trinity the fundamentum fundamenti. He added that the doctrine of the Trinity was fundamental because it was the foundation of so many practical uses, personal holiness, and divine worship (473). For Hoornbeeck, see Johannes Hoornbeeck, Theologiae Practicae (Utrecht, 1663), 1: 136. For the Arminian denial that the Trinity is a 'fundamental article' of the faith, see Muller, PRRD, 4: 109.

22 Polly Ha, Patrick Collinson, eds., The Reception of Continental Reformation in Britain (Oxford University Press for the British Academy, 2010), 235-236.

23 Richard A Muller, PRRD, 4: 144-149.

24 Letham, 'John Owen's Doctrine of the Trinity in its Catholic Context,' 189. Sebastian Rehnman strengthens Muller's case in his contribution to A Companion to Reformed Orthodoxy.

25 As Muller argues, PRRD, 4: 109. 
author. ${ }^{26}$ Letham gives the impression that he is asking the wrong question of the wrong century. The context that he sets for Owen is too narrow in relation to primary sources and too broad in terms of historical setting.

\section{Diminishing Owen's distinctiveness: Paul C.H. Lim}

Paul Lim's analysis slightly diminishes Owen's distinctiveness within the Reformed tradition. He devotes significant attention to Owen's trinitarian theology in his recent book, Mystery Unveiled..$^{27}$ The primary thesis of this book is that the Socinian position on the Trinity represented a consistent application of the Reformed principle of sola scriptura. ${ }^{28} \mathrm{He}$ includes a chapter on Owen and Cheynell and argues that such men tried to revive the doctrine of the Trinity by weaving it into devotion. His assessment is significant; however, it fails to show the integral function of the Trinity in Owen's theology and especially the recurring connection between this doctrine and public worship.

Lim provides valuable insights into how Cheynell and Owen formulated trinitarian spirituality in a polemical context. ${ }^{29}$ Cheynell has received little attention in the secondary literature. Lim shows that most authors treat Puritan spirituality and polemics in isolation from one another instead of as informing one another. Cheynell and Owen remedy this misconception by stressing the devotional aspects of their trinitarian theology in the context of controversy. However, contra the impression given by Lim, Cheynell and Owen are not fully comparable in this regard. Cheynell stressed the Trinity as the object of worship while Owen emphasised the importance of the Trinity in relation to the manner of worship and the personal experience of the worshipers. ${ }^{30}$ Also, much of Cheynell's 'practical' exhortations refer to rejecting Socinian fellowship and to the magistrate's duty to remove them from society. ${ }^{31}$ The

26 A.C. Neele has alerted directed me to Van Mastricht, who showed some concern for Eastern Trinitarianism. In any case, I have not found sufficient evidence of contemporary Eastern influences in Owen.

27 Paul Chang-Ha Lim, Mystery Unveiled: The Crisis of the Trinity in Early Modern England (New York: Oxford University Press, 2012).

28 Lim, Mystery Unveiled, 1, 13-14.

29 Lim, Mystery Unveiled, 215.

30 For Owen, see below. Francis Cheynell, The Divine Trinunity of the Father, Son, and Holy Spirit, Or, the Blessed Doctrine of the Three Coessentiall Subsistents in the Eternall Godhead Without Any Confusion or Division of the Distinct Subsistences or Multiplication of the Most Single and Entire Godhead Acknowledged, Beleeved, Adored by Christians, in Opposition to Pagans, Jewes, Mahumetans, Blasphemous and Antichristian Hereticks, Who Say They Are Christians, but Are Not (London: Printed by T.R. and E.M. for Samuel Gellibrand ..., 1650), 6-7, 182, and especially 272-305. These themes continue through the remainder of the book. These observations also apply to William Perkins, Idolatrie of the Last Times, throughout.

31 Cheynell, Divine Triunity, 417-480. 
material below will show how widely this differs from Owen's practical use of the doctrine.

Lim's treatment of Owen contributes several things to Owen studies. He demonstrates that 'Owen's trinitarian theology hinged on his Christological formulations' ${ }^{32}$ He provides a detailed analysis of how Owen and other Reformed authors largely adopted the medieval interpretation of the Song of Solomon as well. ${ }^{33}$ The most important contribution of his treatment is that he shows how, at various stages in Owen's career, he sharpened his trinitarian spirituality through polemical encounters. This is similar to this writer's observation above regarding the way in which the Arminian context influenced trinitarian piety on the continent. The primary difference here is that Owen aimed at the Socinians rather than the Arminians, while Dutch authors aimed at both. ${ }^{34}$

In spite of its value, Lim's section on Owen contains some deficiencies. He overstates his case in comparing Owen's to the Eastern view of theosis/deification, his dependence upon Calvin's construction of the ontological Trinity, and 'the inherent antinomian potential' that he attributes to Owen's view of Christ's imputed righteousness in justification..$^{35}$

First, endnote seventy-two ${ }^{36}$ inappropriately compares Owen's views to Vladimir Lossky's doctrine of theosis. Lossky is a (controversial) twentieth-century Eastern Orthodox theologian. Lim later refers to Owen's 'theosis-sounding divinity' ${ }^{37}$ Apart from the anachronistic risk involved in comparing a seventeenth-century Reformed theologian with a twentieth-century Eastern Orthodox theologian, the evidence points to the fact that in his mature years Owen believed that being "partakers of the divine nature' (2 Pet. 1:4) entailed renewal in God's image rather than deification. ${ }^{38}$ Ironically, Lim reflects this fact by citing the relevant passage from Owen's Glory of Christ, where he interprets being 'partakers of the divine nature' as being endued with 'the gracious qualifications' with which Christ is endued 'in His human nature'..$^{39}$ Bruce McCormack's research and arguments against importing theosis into Calvin's theology apply with equal force to Owen. ${ }^{40}$ Moreover, later Reformed authors, such as Van Mastricht, regarded the language of deification as dangerous at best and

32 Lim, Mystery Unveiled, 187.

33 Lim, Mystery Unveiled, 193-200.

34 See references above.

35 Lim, Mystery Unveiled, 207.

36 Lim, Mystery Unveiled, 382.

37 Lim, Mystery Unveiled, 209.

38 For example, Owen, The Doctrine of the Saint's Perseverance Explained and Confirmed, Works, 11: 402 .

39 Lim, Mystery Unveiled, 215.

40 Bruce L. McCormack, 'Union with Christ in Calvin's Theology: Grounds for a Divinization Theory?' in Tributes to John Calvin: A Celebration of His Quincentenary, ed. David W. Hall (Phillipsburg, N.J.: P \& R Publishing, 2010), 504-529. 
openly blasphemous at worst. ${ }^{41}$ Lim's comparisons approach the same error of East/ West categorisation that Letham makes and that Muller rejects.

Second, Lim states that Owen followed Calvin in asserting that the Father was the fountain of the deity. ${ }^{42}$ However, Calvin departed from patristic expressions on this point and the evidence is that most of the Reformed orthodox tradition did not follow his construction. ${ }^{43}$ Calvin taught that the Father was the fountain of the Trinity, but he denied that He was the fountain of the deity. The difference was that while other Reformed authors believed that eternal generation had reference to the Son's deity and to His personal subsistence, Calvin denied the former while affirming the later. Perhaps Lim's confusion stems from the fact that Cheynell devoted a section in his massive work on the Trinity to arguing that Calvin did not detach Christ's deity from His personal subsistence in reference to eternal generation. ${ }^{44}$

Third, Lim criticises Owen for going 'slightly' in the direction of Antinomianism by saying that we are freed from obedience. ${ }^{45}$ However, he does not properly acknowledge the Reformed distinction between freedom from obedience in justification as contrasted to sanctification. Owen's position is antinomian only from the standpoint of Richard Baxter's (1615-1691) neonomian position, since Baxter regarded the imputation of Christ's righteousness as inherently antinomian. ${ }^{46}$ If Owen 'tilted' in an antinomian direction, then his teaching on freedom from the law with respect to justification is not proper evidence of the fact. Later Lim adds that Owen was decidedly not antinomian. ${ }^{47}$ However, later still he wrote of the 'inherent antinomian potential'ofOwen's views of imputed righteousness. ${ }^{48}$ This is a theological rather than a historical judgment that assumes the validity of Baxterian and Catholic criticisms against the Reformed doctrine of justification. If the Reformed view of imputed righteousness preceded or was divorced from union with Christ, then it would not simply have 'inherent antinomian potential,' but it would be theological antinomianism outright. ${ }^{49}$ However, by rooting justification in existential union with Christ, Reformed orthodoxy had inherent anti-antinomian tendencies, since union with Christ included renewal in Christ's image. Lim's citation of Richard Hooker concerning participating in Christ by way of imputation and infusion is evidence in this direction. ${ }^{50}$

41 Van Mastricht, Theoretico-Practica Theologia, 792.

42 Lim, Mystery Unveiled, 190.

43 Ellis, Calvin, Classical Trinitarianism, and the Aseity of the Son, chapter one.

44 Cheynell, Divine Triunity, 232-235.

45 Lim, Mystery Unveiled, 201.

46 Tim Cooper, John Owen, Richard Baxter, and the Formation of Nonconformity (Farnham, Surrey, England; Burlington, VT: Ashgate, 2011), 78-83.

47 Lim, Mystery Unveiled, 207.

48 Lim, Mystery Unveiled, 208.

49 See Mark Jones, Antinomianism: Reformed Theology's Unwelcome Guest?, 2013.

50 Lim, Mystery Unveiled, 210. 
Lim's treatment reveals that Owen (and Cheynell) stressed the practical use of the Trinity, but he falls short of revealing how this was so or what this looked like in practice. Upon examination, Cheynell's model was very different than Owen's in that he relegated application to treating the Divine Persons as the object of worship. The material below shows that Lim's analysis leaves Owen's trinitarian piety vague and underdeveloped.

\section{FOUNDATIONS OF OWEN'S TRINITARIAN THEOLOGY}

This preliminary analysis enables us to begin looking into what was distinctive about Owen's trinitarian theology and to explore how his teaching relates to seventeenth century Reformed orthodoxy. Owen's trinitarian theology was the foundation of his trinitarian piety, and his trinitarian piety permeated every area of his theology. This cycle began with his teaching on the knowledge of God and true theology and it found its highest expression in public worship. This section sets the stage for the theological connections drawn in subsequent sections.

\section{The Trinity and true theology}

Owen laid a trinitarian foundation for the knowledge of God. This is particularly evident in his definitions of true or evangelical theology. ${ }^{51}$ Objectively, he defined true theology as a communication from the Father, through the Son, by the Spirit, to the church. ${ }^{52}$ This took the form of objective divine revelation through the prophets and apostles. The triune God committed some of this revelation to writing in Holy Scripture, which constitutes the exclusive saving divine revelation to the church. ${ }^{53}$

Owen added that true theology had a subjective element. The knowledge of God was not only possible because the triune God revealed Himself in Scripture. The renovation of the human mind by the power of the Spirit was needed as well. ${ }^{54}$ This subjective aspect of theology mirrored his objective definition of theology. $\mathrm{He}$ defined it as a communication from the Father through the Son. The Holy Spirit is that which is given as a Spirit of wisdom and revelation..$^{55}$ In his view, possessing

51 This terminology comes from book six of Owen's Theologoumena Pantodapa.

52 Theologoumena, lib. VI, cap. II, 462-463: 'Revalatio autem haec voluntatis divinae, a Patre Christo data, atque ab illo per Spiritum Sanctum cum Apostolis suis aliisque, in usum totius Ecclesiae communicate, Theologiae ista Evangelica, prout in abstracta sumpta doctrinam divinam denotat, quam summus enarraturi.'

53 See John V. Fesko, 'The Doctrine of Scripture in Reformed Orthodoxy,' in Herman J. Selderhuis, ed., A Companion to Reformed Orthodoxy, Brill's Companions to the Christian Tradition (Leiden: Brill, 2013), 429-464.

54 Owen, Theologoumena Pantodapa, 487: 'mentis hominis per Spiritum Sanctum renati.'

55 Theologoumena, lib. VI, cap. VI, 491. For example, 'Nam a Patre hoc donum est per Christum. Datur autem Spiritus Sapientiae et Revelationis.' 
a true theological system without the internal saving work of the triune God is philosophy rather than Christianity. ${ }^{56}$

This resulted in Owen giving great attention to the character of the true theologian. The last section of his massive Theologoumena Pantodapa is devoted to this theme. According to his introduction, this section was the primary aim of the book. In contrast to the claims of some scholars, Owen's Theologoumena was not merely an attempt to present theology in historical progression. ${ }^{57}$ Richard Muller rightly observes that this work was a seventeenth century theological prolegomena. ${ }^{58}$ Owen limited his subject matter to issues affecting the knowledge of God, which included items such as sin and regeneration, and the knowledge of God through Scripture. This is why the book contains lengthy digressions on subjects such as the divine inspiration of Hebrew vowel points. The fact that Theologoumena Pantodapa was a work of prolegomena rather than a historical treatment of the system of theology is readily apparent when comparing its contents to other treatments of the subject, such as that of Johannes Hoornbeeck. ${ }^{59}$ The fact that this work follows a historical order along the lines of divine covenants does not necessarily indicate that it was a covenant theology. His Pneumatologia likewise follows a historical order, ${ }^{60}$ but to this writer's knowledge, no one has claimed that it is a work of covenant theology. We must judge the nature of the treatise by its character and contents rather than by its theological methodology. The material below will demonstrate that covenant theology stood at the heart of his doctrine of the knowledge of God. In this light, it is questionable whether he could have written a prolegomena that was not heavily steeped in covenant theology.

God revealed Himself through the united action of all three Divine Persons. This included the objective content of what God revealed and the subjective appropriation of his revelation by the elect. This involved the ancient doctrine that

56 Owen, Theologoumena, lib. VI, cap. III, 466: 'Doctrinae autem Evangelicae eo modo traditae et expositae notitia aut comprehensio mere naturalis, est Philosophia quaedam Christiana; quae sapientiae omni Graecanicae, seu mere humanae plurimis praeit parasangis.... Eius autem generis est Philosophia haec Christiana, ad omnem ethinicorum hominum sapientiam sive scienciam collata.'

57 Stephen Westcott's English 'interpretation' of this work gives this impression. Sebastian Rehnman refers to this translation as being of 'inferior quality'. Sebastian Rehnman, Divine Discourse: The Theological Methodology of John Owen (Grand Rapids: Baker Academic, 2002), 17. However, even more scholarly treatments of Owen, such as Trueman, treat this book as a work on covenant theology. Trueman, John Owen, 5.

58 Muller, $P R R D, 1: 118$. See also chapter two of my 'Heavenly Directory,' for a fuller reevaluation of the nature of this work.

59 Hoornbeeck, Theologiae-Practicae, 1, chapter one.

60 On the methodology of Owen's work on the Spirit, see Maarten Wise and Hugo Meijer, 'Pneumatology: Tradition and Renewal,' in A Companion to Reformed Orthodoxy, 487-488. The remainder of their chapter provides an extensive analysis of Owen's Pneumatologia with an insightful analysis of Medieval influences on the work. 
the works of the Godhead ad extra are undivided. It included the perichoresis or mutual interpenetration of the Divine Persons. Owen's doctrine of the knowledge of God in this regard reflected not only the Reformed orthodox theological tradition, but the historical expressions of the ancient church. The fact that the subjective appropriation of the revelation of the triune God was part of true theology meant that all true theologians were worshippers of the triune God. In order to worship Him, they must know Him by experiencing communion with the Father, through the Son, by the Spirit.

These emphases laid the foundation both for Owen's entire system of theology and for his theology of worship. They also represent the reasons why these themes converge. If all theology involves knowing God, and the knowing God involves knowing Him as triune, then all theology will be permeated with the Trinity. Continental authors, such as Johannes Wollebius (1589-1629), made this connection explicit by relating almost every major division of theology to the appropriate and distinct, yet united work of all three Divine Persons. ${ }^{61}$ Other theologians, such as William Ames (1576-1633), Herman Witsius (1636-1708), Hoornbeeck, Voetius, and Van Mastricht included the character of the true theologian in their definitions of theology and the knowledge of God..$^{62}$ Owen's later stress on communion with God in public worship combined the ideas that revelation is trinitarian and that the true theologian is a true worshiper. ${ }^{63}$

\section{Communion with the Divine Persons}

Owen's clearest treatment of what communion with the triune God looks like is his work, Communion with God. ${ }^{64}$ This book is the central focus of the handful

61 Joannes Wollebius, Compendium Theologice Christiance. Editio Ultima Prioribus Multo Correctior, 9th ed. (Cantabrigiæ: ex celeberrimæ Academiæ Typographeo, 1654). Though Wisse and Meijer note that he was not always consistent on this point. Maarten Wisse and Hugo Meijer, 'Pneumatology: Tradition and Renewal,' in Companion to Reformed Orthodoxy, 494.

62 William Ames, Medulla S.s. Theologice ... in Fine Adjuncta Est Disputatio De Fidei Divince Veritate. Editio Tertia Priori Longe Correctior. (Apud Robertum Allottum: Londini, 1629), 1; Herman Witsius, On the Character of a True Theologian (Greenville, S.C.: Reformed Academic Press, 1994), 27. Hoornbeeck, Theologicae-Practicae, 1: 4-16; Voetius, Selectarum Dispuationum, 1: 12-28, where he distinguishes 'scholastic theology' from 'true and genuine' theology, even while arguing for the legitimacy of 'scholastic theology'. For Van Mastricht's theological method, see Adriaan Cornelis Neele, Petrus van Mastricht (1630-1706) Reformed Orthodoxy: Method and Piety (Leiden; Boston: Brill, 2009).

63 This idea is also present explicitly in Theologoumena, lib. VI, cap. III, 465.

64 John Owen, Communion with God, in, The Works of John Owen, D.D., ed. William Goold (London; Edinburgh: Johnstone and Hunter, 1850), 2. In A Heavenly Directory, I compare the Goold edition of Owen's works with original printings. In every case that I have researched, Goold has retained the exact words of the original text. The only changes that he made are with reference to numeric variation in Owen's outlines to make reading easier. For this reason, the rest of this essay will cite the Goold edition on the assumption that it reflects the original text accurately. 
of treatments of his trinitarian piety, such as Lim, Kapic, and Kay ${ }^{65}$ However, the themes presented in this work pervade the rest of his writings. His two sermons on The Nature and Beauty of Public Worship are illuminating in this regard. ${ }^{66}$ Here he chose a trinitarian text ${ }^{67}$ in order to describe the primary glory of New Testament worship. This reflects the fact that knowing God as triune was the primary glory of new covenant worship. ${ }^{68}$ William Perkins (1558-1602) similarly concluded his short book on public worship with a trinitarian doxology. ${ }^{69}$ In order to understand the function of the Trinity in Owen's doctrine of public worship, it is necessary to sketch briefly his conception of communion with the persons of the Godhead in his historical context.

Although authors such as Perkins and Cheynell shared Owen's enthusiasm for making the triune God the explicit object of worship, few did so in the way that he did. For example, Stephen Charnock (1628-1680) and Jeremiah Burroughs (16001646), treated public worship extensively without making explicit reference to the Trinity at all. ${ }^{70}$ Owen stood out from others in the way that his doctrine of communion with God as triune informed the experience of the worshiper.

Two overarching principles mark Owen's doctrine of communion with God. The first principle is that since the persons of the Godhead are inseparable yet distinct, they interpenetrate one another (perichoresis). ${ }^{71}$ The second is that the external works of the Godhead are undivided (opera trinitatis ad extra indivisa sunt). ${ }^{72}$ The result of combining these principles is that no one can have communion with one Divine Person without holding communion with all three simultaneously. ${ }^{73}$ Nevertheless, the Scriptures often ascribe some aspect of a divine peculiarly to one Divine Person. These were called opera appropriata. ${ }^{74}$ In his Hebrews commentary, Owen illustrated this principle in relation to the doctrine of revelation. Since the Father is the fount of

65 Lim, Mystery Unveiled; Kapic, Communion with God; Kay, Trinitarian Spirituality.

66 Owen, 'The Nature and Beauty of Public Worship,' Works, 9.

67 Eph. 2:18: 'For through Him we both have access by one Spirit unto the Father.'

68 Owen, 'The Chamber of Imagery of the Church of Rome Laid Open,' Works, 8: 555-556.

69 Perkins, Idolatry of the Last Times, 181.

70 Stephen Charnock, Discourses Upon the Existence and Attributes of God. 2 Vols. ([S.1.]: Baker Book House, 1853), 109ff; Jeremiah Burroughs, Gospel-Worship, Or, the Right Manner of Sanctifying the Name of God in General and Particularly in These Three Great Ordinances, Viz. 1. Hearing of the Word, 2. Receiving the Lords Supper, 3. Prayer (London: Printed by Peter Cole ..., 1658). For an analysis of these authors, see chapter three of my A Heavenly Directory.

71 Owen, Vindiciae Evangelicae, Works, 12: 73.

72 Owen, Pneumatologia, Works, 3: 66-68, 93. See also Edward Leigh, A Systeme or Body of Divinity Consisting of Ten Books, Wherein the Fundamentals and Main Grounds of Religion Are Opened ... (London: Printed by A.M. for William Lee ..., 1662), 205.

73 Owen, Communion with God, Works, 2: 268-269.

74 For opera appropriata, see Muller, PRRD, 4: 267-269. 
the deity, He is the origin of all divine works. ${ }^{75}$ His appropriate work is initiation. ${ }^{76}$ As the Son fulfils the Father's plan respecting the elect and the Spirit brings this plan to fruition by applying redemption to them, ${ }^{77}$ so divine revelation in Scripture originates with the Father. ${ }^{78}$ The Father revealed His counsel to His Son who, in turn, revealed it to mankind. ${ }^{79}$ The Spirit takes the Father's revelation, both through reading and preaching the word, and He applies it to His people. ${ }^{80}$ Though all three Divine Persons work simultaneously, they do not act in the same way. ${ }^{81}$ However, they do not contribute to three parts of a single work. They accomplish a single work in a threefold manner. It is clear that this observation parallels his treatment of true theology. It shows where the objective and subjective elements of theology converge in regenerate people. The same pattern is present in Christ's incarnation, which Owen treats elsewhere. ${ }^{82}$

These distinctions shape how believers hold communion with all three Divine Persons. The trinitarian doxology found in 2 Cor. 13:14 sets the tone for the nature of communion with each Divine Person. In this text, the Father is characterised by love, the Son by grace, and the Spirit by comfort. ${ }^{83}$ The fact that the Father is characterised by love, does not exclude the Son and the Spirit from the exercise of divine love. However, the Father is viewed as the fountain of divine love. ${ }^{84}$ The Father's love is like the sun while the Son's love is like the rays of the sun. ${ }^{85}$ Interestingly, medieval theology, following Augustine, associated love primarily with the Holy Spirit, who was the bond of love between the Father and the Son. ${ }^{86}$ Owen reassessed this trend in light of passages such as 1 John 4, which declared that 'God is love' because $\mathrm{He}$ sent His Son to die for sinners. 'God' in this and other passages refers clearly to the Father. ${ }^{87}$ This observation opens the door to further research regarding the

75 Owen, Hebrews, Works, 20: 23, 34; Salus Electorum Sanguis Christi, or, The Death of Death in the Death of Christ, Works, 10: 163-173. Chapters 4-6 of this work treat the appropriate works of the Father, Son, and Spirit in redemption, respectively.

76 Owen, Communion with God, Works, 2, chapter 4.

77 Owen, Death of Death in the Death of Christ, Works, 10: 174-177 and 178-179, respectively.

78 Owen, Hebrews, Works, 20: 34-35.

79 Owen, Hebrews, Works, 20:35, 97. See also the section above treating Theologoumena Pantodapa.

80 Owen, Hebrews, Works, 20: 35-36.

81 Leigh, Body of Divinity, 205.

82 Owen, Pneumatologia, Works, 3: 162ff.

83 Owen, Communion with God, Works, 2: 19-20.

84 Owen, Nature and Beauty of Public Worship, Works, 9: 58-59.

85 Owen, Communion with God, Works, 2: 27.

86 This is reflected repeatedly most of the chapters of the Oxford Handbook of the Trinity.

87 Owen, Communion with God, 17-18; Works, 2: 19-20. 
interaction between Reformed Trinitarianism and the medieval tradition. ${ }^{88}$ Owen did not merely regurgitate this tradition. He was willing to modify it in light of his exegetical labours. ${ }^{89}$

Without repeating what I have written elsewhere,$^{90}$ it is sufficient to summarise how these principles apply to public worship. Owen taught that the primary goal in public worship was to come to the Father. ${ }^{91}$ However, both in terms of space and emphasis, most of his attention went to the Divine Person and work of the Son. ${ }^{92}$ Communion with God in public worship, or anywhere else, would be impossible without communion with the Son in grace. ${ }^{93}$ In His personal grace, He is endowed with every excellence of divine wisdom and power needed to save sinners. ${ }^{94}$ Through His purchased grace, believers receive forgiveness of sin and imputed righteousness through His obedience..$^{95}$ No one can know the Father's love except through the Son's grace. ${ }^{96}$ Christ is the covenant bond that unites believers to Him and brings

88 Some of his contemporaries did not share these emphases. Richard Byfield ignored the person of the Father when treating 'God is love,' even though his book included the Divine Persons in its title. Richard Byfield, The Gospels Glory, Without Prejudice to the Law Shining Forth in the Glory of God [brace] the Father, the Sonne, the Holy Ghost, for the Salvation of Sinners, Who Through Grace Do Believe According to the Draught of the Apostle Paul in Rom. 8.ver. 3.4. Held Out to Publick View. (London: Printed by E.M. for Adoniram Byfield, 1659), 58-59.

89 This vindicates Muller's assertion that the primary contribution of the Reformed to trinitarian theology was likely exegetical. Muller, PRRD, 4: 25. For Owen's exegetical method, see Henry M. Knapp, 'Understanding the Mind of God: John Owen and Seventeenth-Century Exegetical Methodology,' 2002.

90 A Heavenly Directory, chapter two.

91 Owen, Nature and Beauty of Public Worship, Works, 9: 58-60.

92 This is truth, both in regard to Communion with God and to The Nature and Beauty of Public Worship.

93 Owen, Nature and Beauty of Public Worship, Works, 9: 61.

94 Owen, Communion with God, Works, 2: 59-117. Byfield called this 'the grace of personal union.' Richard Byfield, The Gospel's Glory Without Prejudice to the Law, 73.

95 Owen, Communion with God, 181-187; Works, 2: 159-164. For John Owen's views on justification, including the 'active obedience' of Christ, see Carl R. Trueman, John Owen, 101-121; and 'John Owen on Justification,' in Justified in Christ: God's Plan for us in Justification, ed. K. Scott Oliphint (Geanies House, Scotland: Christian Focus Publications, 2007), 81-98. For arguments that the Westminster documents imply the active obedience of Christ, see Alan D. Strange, 'The Imputation of the Active Obedience of Christ at the Westminster Assembly,' in Drawn into Controversie, 31-51. Strange attempts to explain the changes between Westminster and Savoy as well (31).

96 Owen, 'Nature and Beauty of Gospel Worship,' Works, 9: 61. 
them into communion with the Father. ${ }^{97}$ The Spirit is the comforter because the Spirit applies the grace of Christ so that believers can know the love of the Father. ${ }^{98}$

If the work of any Divine Person is omitted or altered, then people cannot hold communion with God at all. In Owen's view, Roman Catholicism obliterated communion with God by altering the Christ's work. As a result, the outward pomp and ceremony of their worship services reflected an attempt to compensate for the absence of the Holy Spirit. ${ }^{99}$ Positively, because the knowledge of God is trinitarian, communion with God involves all three Divine Persons. ${ }^{100}$ Regenerate people are worshipers. True worshipers desire to be where God is present most gloriously and powerfully. This occurs in public worship above all other places.

\section{Conclusion: Public worship as the culmination of trinitarian piety}

Owen's associate minister, David Clarkson (1622-1686), published a sermon entitled, Public Worship to be Preferred Above Private. ${ }^{101} \mathrm{He}$ argued that this was the case based, among other things, on God's promises and on the fact that He loves to have all of His children present at once. ${ }^{102}$ Owen and Clarkson clearly shared an emphasis on communion with God in public worship. However, Owen's treatment of this theme was consistently trinitarian while Clarkson's was not. Even where Clarkson addressed communion with the Godhead elsewhere, he highlighted communion with the Father and the Son to the neglect of the Spirit. ${ }^{103}$ What makes Owen distinctive is that where he treated communion with the triune God, he included public worship as its high point, ${ }^{104}$ and where he treated public worship, he included communion with the triune God as its highest privilege. ${ }^{105}$ This feature of his theology is frequently

97 Van Mastricht, Theoretico-Practica Theologia, 791: 'Quid sit union cum Christo? ... quod sit mystica illa relatio, per quam uniti cum Christo ius aquirunt ad omnes illas benedictiones, qua in ipso preparantur.' (Trans: 'What is union with Christ? . . . That it is a mystical relation, by which we are united with Christ and acquire the right to all His blessings, which are provided in him.'). Owen, Nature and Beauty of Public Worship, Works, 9: 70. For more about Owen's teaching on the Spirit, see Ryan M. McGraw, 'John Owen on the Holy Spirit in Relation to the Trinity, the Humanity of Christ, and the Believer,' in The Beauty and Glory of the Holy Spirit, ed. Joel R. Beeke and Joseph A. Pipa (Grand Rapids, 2012), 267-284. For a groundbreaking treatment of the medieval background of Owen's treatment of the Holy Spirit in relation to Christ's humanity, see Wise and Meijer, 'Pneumatology: Tradition and Renewal,' in Companion to Reformed Orthodoxy, 465-518.

99 Owen, The Chamber of Imagery, Works, 8: 557-560.

100 Owen, The Nature and Beauty of Gospel Worship, Works, 9: 57.

101 David Clarkson, Public Worship to be Preferred Before Private, The Works of David Clarkson. (Edinburgh: Banner of Truth Trust, 1988), 3: 187-209.

102 Clarkson, Public Worship, Works, 3: 190-194.

103 Clarkson, Believers' Communion with the Father and the Son, Works, 3: 166-186.

104 Owen, Communion with God, Works, 2: 259-260.

105 For example, the two sermons on The Nature and Beauty of Public Worship, cited above. 
neglected in recent treatments. The rest of this article solidifies this point by showing how these themes pervaded every major area of his theology.

\section{TRINITY AND SCRIPTURE}

The trinitarian foundations of the knowledge of God and the trinitarian experience of communion with God are two streams that frequently flow together in Owen's writings. One obvious place where this is the case is in regard to his doctrine of Scripture. The reason is that the doctrine of Scripture is intimately tied to Reformed prolegomena on the one hand, ${ }^{106}$ and it served as the foundation for the Reformed doctrine of worship on the other. ${ }^{107}$ Owen's trinitarian construction of the knowledge of God combined with the Reformed doctrine of the sufficiency and authority of Scripture, resulted in a doctrine of public worship that was both Reformed and devotionally trinitarian.

The Reformed principle of public worship teaches that the church must limit the ordinances of public worship to those which God has appointed in Scripture. ${ }^{108}$ The form of these ordinances should be informed and directed by Scripture, while falling short of imposing a set form of words. ${ }^{109}$ For instance, it is a divine ordinance to pray, however, the church cannot require ministers to submit to pre-composed prayers in a prayer book. ${ }^{110}$ Owen argued that imposing prayers composed by the church upon ministers would prevent them from exercising spiritual gifts in prayer and that if ministers did not exercise these gifts then they would lose them. ${ }^{111}$ Anything that has religious significance in worship that God has not required in Scripture is forbidden by Scripture. Decades prior to Owen, William Ames noted that the Church

106 Muller, $P R R D, 2$.

107 Savoy Declaration of Faith, 1.6.

108 Savoy Declaration 22.1; Westminster Confession 21.1; George Gillespie, A Dispute Against the English Popish Ceremonies Obtruded on the Church of Scotland: Wherein Not Only Our Own Arguments Against the Same Are Strongly Confirmed, but Likewise the Answers and Defences of Our Opposites, Such as Hooker, Morton, Burges, Sprint, Paybody, Andrews, Saravia, Tilen, Spotswood, Lindsey, Forbes, Etc., Particularly Confuted, ed. Christopher Coldwell (Dallas, TX: Naphtali Press, 1993), 112; William Ames, A Fresh Suit Against Human Ceremonies in Gods Worship or a Triplication Unto D. Burgesse His Rejoinder for D. Morton, ... (by William Ames.). ((S.1.), 1633).

109 For example, this terminology is applied to prayer in Westminster Shorter Catechism 99; Westminster Larger Catechism 186.

110 Church of Scotland. General Assembly, England and Wales. Parliament, and Westminster Assembly, A Directory for the Publique Worship of God Throughout the Three Kingdoms of England, Scotland, and Ireland Together with an Ordinance of Parliament for the Taking Away of the Book of Common-Prayer: And for Establishing and Observing of This Present Directory Throughout the Kingdom of England and Dominion of Wales ... (London: Printed by M.B. and A.M. for the Company of Stationers, 1646), 1-4. Owen, The Work of the Holy Spirit in Prayer, Works, 4: 339.

111 Owen, Work of the Holy Spirit in Prayer, Works, 4: 239-240. 
of England, mistakenly in his view, tried to introduce new ordinances of worship by saying that they were merely circumstances surrounding worship and that they did not alter the substance of the divine service. ${ }^{112}$ George Gillespie (1613-1648) later clarified that genuine circumstances of worship could be no essential part of worship, they must be necessary in order to observe the ordinances that God had commanded, and they must not be determinable by Scripture. ${ }^{113}$ Thus, the church must select a time of day on the Lord's Day in order to hold services, ${ }^{114}$ but the church cannot use candles in the worship service for anything other than lighting. ${ }^{115} \mathrm{I}$ have shown elsewhere that Owen and his contemporaries developed these principles from the second commandment. ${ }^{116}$

Owen's treatment of the principles governing biblical worship was distinctively trinitarian. This is obvious on the surface from his two sermons on the Nature and Beauty of Public Worship, which argue for the principles stated above in connection to a passage that teaches communion with God as triune. This was not the case with many of his contemporaries, who often treated the biblical principles governing worship and the need to come to God with a regenerate heart. Charnock and Burroughs did not treat the Trinity at all in relation to their treatises on worship. ${ }^{117}$ As noted above, authors who did connect the Trinity to worship, such as Perkins and Cheynell, treated the triune God as the object of worship without showing how communion with the three Divine Persons affected the manner of worship. ${ }^{118}$ The principles of regeneration and worship overlap with Reformed prolegomena in relation to the knowledge of God, as shown above. However, the former group of authors cited here treated communion with God to the neglect of the Trinity while the latter included the Trinity to the neglect of distinct communion with the Divine Persons. Owen stands out by self-consciously interweaving these themes. As a result, his treatment of the Reformed doctrine of public worship represents a consistent outworking of his trinitarian prolegomena, of which the doctrine of Scripture was one of the two primary first principles. Owen's Trinitarianism worked itself out with at least more consistency and rigor than other British Reformed orthodox theologians.

\section{TRINITY AND SPIRITUAL AFFECTIONS}

\footnotetext{
112 Ames, A Fresh Suit, Part I, 37.

113 Gillespie, English Popish Ceremonies, 112-115. I am grateful to Chris Caldwell for this reference.

114 Ames, A Fresh Suit, Part I, 58-59.

115 Ames, A Fresh Suit, Part I, 16, 17-18, respectively. Nicholas Tyacke notes that in 1640,Thomas Warmstry complained that churches had introduced 'candles in the day time'. Nicholas Tyacke, Anti-Calvinists: The Rise of English Arminianism, C. 1590-1640 (Oxford; New York: Clarendon Press; Oxford University Press, 1987), 241.

116 McGraw, A Heavenly Directory, chapter 3.

117 Charnock, Existence and Attributes of God, 1: 109ff.; Burroughs, Gospel Worship.

118 Perkins, Idolatry of the Last Times, throughout; Cheynell, Divine Triunity, 272-305.
} 
Owen's teaching on spiritual affections integrated the themes of Trinity and public worship in several ways. He illustrated this connection particularly in relation to proper and improper affections towards the ordinances of worship and the related topic of apostasy. He included chapters on public worship both in his book on The Grace and Duty of Being Spiritually Minded and in his work on Apostasy from the Gospel. ${ }^{119}$ These connections not only strengthened Owen's teaching on the trinitarian nature of communion with God, but they reinforced the distinctive nature of his contribution to Reformed trinitarian theology by his intentional inclusion of public worship in works such as these.

In Puritan thought, the affections ordinarily encompassed the emotive capacity of the soul, which sometimes includes the will. ${ }^{120}$ The subject of the spiritual affections lay at the heart of Puritan experimental piety. ${ }^{121}$ Renewed affections that love the Divine Persons are perhaps the primary mark of a regenerate soul. ${ }^{122}$ In relation to the ordinances of public worship, spiritual affections are necessary in order to hold communion with the triune God. Owen developed this theme both positively and negatively.

First, and positively, believers must love the ordinances of worship that God has appointed. ${ }^{123} \mathrm{~A}$ regenerate soul only loves those things that God has commanded. The better informed such affections are, then the more closely will worship naturally follow the principles outlined above in relation to Scripture. Regenerate souls love the Scriptures because they love God through the Scriptures. ${ }^{124}$ They will love those ordinances that God appointed only. Right affections should love no other ordinances. This is merely one example of his positive treatment of the importance of the affections in communing with God in public worship. ${ }^{125}$

119 Both treatises are found in Owen, Works, 7. The chapters on worship in The Grace and Duty are found on pp. 416-445. The material in Apostasy from the Gospel is found in chapter six of that book.

120 Owen, Grace and Duty, Works, 7: 270; Edward Reynolds, A Treatise on the Passions and Faculties of the Soul, With the Several Dignities and Corruptions Belonging Thereunto (London, 1658), 896, 1104-1105; Jonathan Edwards, The Religious Affections, in The Works of Jonathan Edwards, ed. Perry Miller, John E Smith, and Harry S Stout (New Haven, Conn; London: Yale University Press; Oxford University Press, 2008), 2: 96.

121 For example see, Edward Reynolds, Meditations on the Fall and Rising of St. Peter (London: Printed for Thomas Parkhurst ..., 1677). 58: 'Christ is not truly apprehended either by the fancy or the understanding. He is at once known and possessed. It is an experimental, and not a speculative knowledge that conceives Him; he understands Him that feels Him. We see Him in His grace and truth, not in any carnal or gross pretense.'

122 Jonathan Edwards, 'True Grace Distinguished from the Experience of Devils,' in The Works of Jonathan Edwards (Edinburgh: The Banner of Truth Trust, 1997), 2: 48-49.

123 Owen, Grace and Duty, 234; Works, 7: 432.

124 Owen, Grace and Duty, 237; Works, 7: 434. Here he explains that the saints have communion with God in worship through faith, love, and delight.

125 For a fuller analysis, see McGraw, 'A Heavenly Directory, ' chapter 4. 
However, second, people may have wrong or misplaced affections in relation to the true ordinances of God. For example, they may trust in them instead of using them as divinely appointed means of communion with God. ${ }^{126}$ They may love the right way of worship for the wrong reasons. ${ }^{127}$ They may also love their own particular faction more than God and their zeal for the ordinances of worship degenerates into spiritual pride instead of genuine fellowship with the Father, through the Son, by the Spirit. ${ }^{128}$

The consequence of this negative point is apostasy from the gospel. Owen described this apostasy as a gradual and incremental process. This process begins with neglecting the ordinances of public worship and then moves through adding man-made ordinances to divine worship and trusting the ordinances themselves instead of God through them. ${ }^{129}$ Similarly, he asserted in the Grace and Duty of Being Spiritually Minded that while neglecting the ordinances of God entirely is not the only means of apostasy, it is a sure path to apostasy. ${ }^{130}$ All three of these points together reflect the fact that just as public worship is the climax of communion with God, so communion with God must be the goal of public worship. Exalting anything else above the triune God and communion with Him is the essence of apostasy.

The connection between spiritual affections, trinitarian theology, and public worship as communion with the triune God must always be the goal of public worship. In other words, since public worship is the highest possible experience of communion with God, Owen saw fit to include this subject in his treatments of the spiritual affections and of apostasy, which address the progress and decline of communion with God, respectively. He did not always treat all three Divine Persons in the same sections of these works as he did elsewhere, but all three persons pervade these discussions as a whole. This material further strengthens the fact that the connection between communion with God and public worship was intentional and a self-conscious emphasis. This grew out of the practical emphasis of Reformed Trinitarianism, which I have argued above was one of its distinguishing traits and one of its primary contributions to the history of the doctrine.

\section{TRINITY AND COVENANT}

In Reformed theology, Trinity, covenant, and the experiential knowledge of God are intertwined. Owen made this clear by including the covenantal bond between God and believers in Christ in the heart of his definition of communion with God. ${ }^{131}$ As it relates to the Trinity, there are two primary aspects of covenant theology in relation

126 Owen, Grace and Duty, Works, 7: 424.

127 Owen, Grace and Duty, Works, 7: 425.

128 Owen, Grace and Duty, Works, 7: 428.

129 See chapter three of McGraw, 'A Heavenly Directory.'

130 Owen, Grace and Duty; Works, 7: 434.

131 Owen, Communion with God, Works, 2: 8. 
to Christ: the eternal covenant of redemption and the historical covenant of grace. The first covenant stressed the work of the Son in relation to the Father, while the second shifted emphasis to the work of the Son in relation to the Spirit. There is also a difference in the degree of communion with God between worship under the old and new covenants. This meant that Owen's covenant theology was both trinitarian in its structure and doxological in its goals.

The intra-trinitarian covenant of redemption rose to prominence in the $1640 \mathrm{~s}^{132}$ The idea existed much earlier, but the terminology describing it evolved gradually. ${ }^{133}$ Some authors referred to it as the covenant of redemption ${ }^{134}$ while others called it the counsel of peace. ${ }^{135}$ Owen most commonly called this covenant the "covenant of the Mediator' ${ }^{136}$ The covenant of redemption involves primarily the Father and the Son as parties of the covenant. ${ }^{137}$ The Son voluntarily condescended to purchase the people whom the Father chose to salvation. ${ }^{138}$ This meant that He would become incarnate, live, die, rise, and ascend into heaven as the God-man. The Father promised to assist the Son in His work and to give Him a redeemed people out of all the nations of the earth as His inheritance. ${ }^{139}$ This covenant represents the eternal decree of God as it relates to the plan of redemption. ${ }^{140}$

Where does the Holy Spirit factor into this construction of covenant theology? Robert Letham's preoccupation with the question of East versus West spills over into his examination of Owen on the covenant of redemption. He criticises Owen for his 'binitarian construction' of the covenant of redemption. ${ }^{141}$ He regards this as

132 Trueman, John Owen, 71, where he notes the importance of David Dickson in the Englishspeaking context. For Dickson's exposition of the covenant of redemption, see his comments on Psalm 2: 7-9. David Dickson, A Brief Explication of the First Fifty Psalms, second edition (London, 1655), 11-13.

133 Richard A. Muller, 'Toward the Pactum Salutis: Locating the Origins of a Concept,' Mid-America Journal of Theology 18 (2007): 11-65.

134 Patrick Gillespie, The Ark of the Covenant Opened, Or, a Treatise of the Covenant of Redemption Between God and Christ, as the Foundation of the Covenant of Grace the Second Part, Wherein Is Proved, That There Is Such a Covenant, the Necessity of It, the Nature, Properties, Parties Thereof, the Tenor, Articles, Subject-Matter of Redemption, the Commands, Conditions, and Promises Annexed, the Harmony of the Covenant of Reconciliation Made with Sinners, Wherein They Agree, Wherein They Differ, Grounds of Comfort from the Covenant of Suretiship (London: Printed for Tho. Parkhurst ..., 1677).

135 Wilhemus A'Brakel, The Christian's Reasonable Service, ed. Joel R. Beeke, trans. Bartel Elshout, 4 vols. (Grand Rapids: Reformation Heritage Books, 2012). See volume 1, chapters 4-7.

136 For example, Owen, Hebrews, Works, 20: 61. This terminology appears throughout the Hebrews commentary.

137 The Sum of Saving Knowledge with the Practical Use Thereof (Edinburgh, 1671), heading 2 (unpaginated).

138 Owen, Death of Death, Works, 10: 174.

139 Owen, Hebrews, Works, 20: 61-62. On pp. 194-195, Owen listed sixteen actions of the Father towards the Son in the covenant of redemption.

140 Muller, 'Toward the Pactum Salutis,' 61-63.

141 Letham, 'John Owen's Doctrine of the Trinity in its Catholic Context,' Ashgate Research Companion, 196. 
reflecting the Western tendency to subordinate and depersonalise the Holy Spirit. ${ }^{142}$ However, Jonathan Edwards (1703-1758) later clarified the role of the Spirit in the covenant of redemption. He argued that the Spirit is active in the covenant of redemption, but He is not a party in that covenant because $\mathrm{He}$ is not humiliated. The Son's humiliation is vital to His being a party in the covenant of redemption. On the other hand, the Spirit is actively involved in the covenant because He cannot be inactive without dividing the Godhead. ${ }^{143}$ Edwards did not invent this explanation, but he elaborated it more clearly than most earlier Reformed authors. ${ }^{144}$ Letham argues that Owen was allegedly aware of the danger that the covenant of redemption posed to the Trinity and that it implied that the persons of the Godhead needed a covenant to unite them in their purpose. ${ }^{145} \mathrm{He}$ concluded that Owen's difficulty with treating the Divine Persons adequately betrays his Western roots. ${ }^{146} \mathrm{He}$ adds that the East stresses that we know the persons by our relation to them in redemption rather than by definition. However, this was precisely Hoornbeek's conclusion to his treatment of the Trinity ${ }^{147}$ and it pervades Peter van Mastricht's chapters on the three persons. ${ }^{148}$ Earlier in the Ashgate volume, Willem van Asselt argued that the trinitarian structure of the covenant of redemption was precisely what enabled Owen and Cocceius to emphasise communion with all three Divine Persons. ${ }^{149}$

The covenant of grace completes the trinitarian picture of Reformed covenant theology. In the covenant of grace, the Son fulfils the terms of the Father's plan in the eternal covenant of redemption by actually purchasing salvation. In the covenant of grace, Christ fulfilled the covenant of works that Adam broke in the Garden of Eden. ${ }^{150}$ This covenant required perfect and perpetual obedience in order to receive

142 Carl Trueman criticises in passing Letham's charge that the covenant of redemption introduced tension into the theology of the Westminster Standards. Carl. R. Trueman, 'Reformed Orthodoxy in Britain,' in Companion to Reformed Orthodoxy, 282, fn 82.

143 Jonathan Edwards, 'Economy of the Trinity in the Covenant of Redemption,' The Works of Jonathan Edwards Online, 20: 441-442.

144 Van Asselt makes a similar observation about Cocceius's position. W. J. van Asselt, The Federal Theology of Johannes Cocceius (1603-1669) (Leiden; Boston: Brill, 2001), 235.

145 Letham, 'John Owen's Doctrine of the Trinity in its Catholic Context,' Ashgate Research Companion, 196.

146 Letham, 'John Owen's Doctrine of the Trinity in its Catholic Context,' Ashgate Research Companion, 197.

147 Hoornbeeck, Theologiae Practicae, 1: 139-141.

148 Peter van Mastricht, Theoretico-Practica Theologia. Qua, Per Singula Capita Theologica, Pars Exegetica, Dogmatica, Elenchtica \& Practica, Perpetua Successione Conjugantur. (Trajecti ad Rhenum, \& Amstelodami: Sumptibus Societatis, 1724), 235-270.

149 Van Asselt, 'Covenant Theology as Relational Theology,' Ashgate Research Companion, 77.

150 Herman Witsius, De Oeconomia Foederum Dei Cum Hominibus Libri Quatuor, 2 vols. (Trajecti ad Rhenum: apud Franciscum Halmam, Gulielmum van de Water, 1694). lib. 1, cap. 9, paragraph XXIII (p. 126): 'Foedus gratia non est abolitia foedus operum, sed confirmation illius, in quantum Mediator omnes conditiones foederis implevit, adeo ut juxta foedus operum, cui a Mediatore satisfactum est, fideles omnes justificentur et serventur.' 
the promise of eternal life. ${ }^{151}$ Christ not only kept the law of the covenant of works for His people, but He bore the curse of the covenant, which Adam brought upon himself and his posterity. ${ }^{152}$ The covenant of grace fulfils the covenant of redemption by satisfying the terms of the covenant of works. One difference between the covenant of grace and the covenant of redemption is that the covenant of grace requires a response from the elect in order to make them partakers of Christ and His benefits. This response is faith in Christ, which unites the souls of believers to their Saviour. This is where the Holy Spirit becomes prominent, since it is He who applies the redemption purchased by Christ to His people. ${ }^{153}$ This means that even though Christ and the Father are the parties of the covenant of redemption, and Christ and believers are the primary parties of the covenant of grace, neither covenant could come to fruition or fulfil the divine plan of redemption without the powerful operation of the Holy Spirit. Mirroring his description of communion with God, ${ }^{154}$ Christ is the centrepiece of both covenants since He is the ground of communion between God and sinners.

How does Owen's theology of public worship relate to this trinitarian structure of Reformed covenant theology? The answer lies in the relationship between what Owen and others called the old covenant and the new covenant. Based largely on Hebrews 8, most Reformed authors agreed that the 'old covenant' referred to the Mosaic covenant. ${ }^{155}$ The primary point of dispute was how the old covenant related to the covenant of works and the covenant of grace. Mark Jones argues that most Reformed authors believed that the Mosaic covenant was an administration of the covenant of grace with the covenant of works present in a subordinate and declarative sense. ${ }^{156}$ John Ball made a similar claim about his contemporaries. ${ }^{157}$ Under this view, the old covenant people of God were not under the law as a covenant of works. They lived by and under the terms of the covenant of grace in light of the promises that God gave to Abraham. However, the Ten Commandments were not only a rule of life for believers within the covenant of grace. They represented the standard and the sanction of the broken covenant of works that Christ needed to keep in order to

151 Savoy Declaration 7.2.

152 Savoy Declaration 8.1-3.

153 Owen, 'The Everlasting Covenant,' Works, 9: 418.

154 Owen, Communion with God, Works, 2: 8.

155 Brian J. Lee, Johannes Cocceius and the Exegetical Roots of Federal Theology, Reformed Historical Theology (Göttingen: Vandenhoeck \& Ruprecht, 2008), chapter 3.

156 Mark Jones, 'The 'Old' Covenant,' in Michael A.G. Haykin and Mark Jones, eds., Drawn into Controversie: Theological Diversity and Debates within Seventeenth-Century British Puritanism (Gottingen: Vandenhoeck \& Ruprecth, 2011), 200.

157 John Ball, A Treatise of the Covenant of Grace Wherein the Graduall Breakings Out of Gospel Grace from Adam to Christ Are Clearly Discovered, the Differences Betwixt the Old and New Testament Are Laid Open, Divers Errours of Arminians and Others Are Confuted, the Nature of Uprightnesse, and the Way of Christ in Bringing the Soul into Communion with Himself ... Are Solidly Handled (London: Printed by G. Miller for Edward Brewster, 1645), 95. 
fulfil the covenant of redemption. ${ }^{158}$ By contrast, Owen taught a minority view that the old or Mosaic covenant was neither the covenant of works nor the covenant of grace, but that it was a 'superadded covenant' ${ }^{159} \mathrm{~A}$ few others, such as John Cameron and Samuel Petto, held a similar view. ${ }^{160}$ In Owen's view, Israel could not be under the covenant of works, since it was abrogated as a way of life immediately upon Adam's fall. ${ }^{161}$ However, the Mosaic covenant could not be an administration of the covenant of grace, since he believed that Hebrews contrasted this covenant with the benefits of the new covenant, such as the forgiveness of sins. Instead, the Mosaic covenant presents the 'legal condition' of the covenant of grace as the means by which Christ would redeem His people. ${ }^{162}$ The Old Testament saints did not directly have any relationship to the covenant of works or the covenant of grace by virtue of the Mosaic covenant. ${ }^{163}$

While the end results of Owen's minority construction of the Mosaic covenant differed little from other Reformed authors, he used it as an avenue to draw attention to the superior glory of new covenant worship. ${ }^{164}$ As noted above, he believed that the primary advantage of new covenant worship was knowing God as triune. ${ }^{165}$ This does not mean that the Old Testament did not include hints at God's triunity. He argues at length that it did in the first two volumes of his work on Hebrews. His colleague and friend, Thomas Goodwin (1600-1680), went so far as to argue that if the doctrine of the Trinity was not at least present seminally in the Old Testament, then it is not a biblical doctrine, since the New Testament expands the doctrines of the Old Testament. ${ }^{166}$ What Owen was driving at was that the new covenant revealed the experimental knowledge of all three persons in the Godhead in a way

158 J. Mark Beach, Christ and the Covenant: Francis Turretin's Federal Theology as a Defense of the Doctrine of Grace (Göttingen: Vandenhoeck \& Ruprecht, 2007), 311-316.

159 Owen, Hebrews, Works, 23: 70.

160 Samuel Petto, The Difference Between the Old and New Covenant Stated and Explained with an Exposition of the Covenant of Grace in the Principal Concernments of It (London: Printed for Eliz. Calvert ..., 1674), 162. Michael Brown has recently misconstrued the relationship between Owen and Petto's views in this regard. See Michael Brown, Christ and the Condition: The Covenant Theology of Samuel Petto (1624-1711) (Grand Rapids, Michigan: Reformation Heritage Books, 2012); and Ryan M. McGraw, 'A Review of Michael Brown, Christ and the Condition: The Covenant Theology of Samuel Petto (1624-1711),' Mid-America Journal of Theology 23 (2012): 152-155 for my critique of his analysis.

161 Ball, A Treatise of the Covenant of Grace, 107.

162 Petto, The Difference, 168: 'I do not call it, the Covenant of Grace, nor the Covenant of Works; but to express the formality and essential nature of it, I call it, the Covenant of Grace as to its legal condition, or a covenant concerning the legal condition of the covenant of grace.' Emphasis original.

163 See Jones, 'The 'Old' Covenant,' 199-200.

164 Owen, Hebrews, Works, 23: 73-75

165 Owen, 'The Chamber of Imagery of the Church of Rome Laid Open,' Works, 8: 555-556.

166 Thomas Goodwin, The Knowledge of the Father and of His Son Jesus Christ, The Works of Thomas Goodwin. (Edinburgh: J. Nichol, 1861), 4: 352-353. 
that surpassed the experience of the old covenant saints, both in its revelation and in its power. The book of Hebrews was particularly important in this connection, since Owen believed that the primary purpose of the book was to argue that Christ had the authority to change and remove the Mosaic ordinances of public worship. ${ }^{167}$ Elsewhere, he argued that this meant that Christ exchanged the outward glory of old covenant temple worship for 'a few and simple ceremonies'. ${ }^{168}$

In the old covenant, the external ordinances of worship were more glorious, while the saint's internal communion with God was less powerful. In the new covenant, the external ordinances of worship were reduced to elements such as prayer, the ministry of the word, and the administration of the sacraments, but the saints enjoyed communion with the triune God that surpassed anything that the old covenant saints knew. ${ }^{169}$ In this way, Owen's covenant theology wove together his trinitarian theology as it related to the knowledge of God, Scripture, spiritual affections, and other subjects. Once again, public worship is the common thread tying these doctrines together. Simultaneously, his treatment of communion with God in new covenant worship is intertwined with his Ecclesiology.

\section{TRINITY AND ECCLESIOLOGY}

Ecclesiology is the locus of theology in which Owen gave concrete expression to how believers hold communion with the triune God in public worship. Most of the sections above refer to the ordinances of public worship. Seventeenth century Ecclesiology treated these ordinances directly. This is the point at which Owen showed how divine ordinances related to communion with the Godhead. Due to space limitations, this analysis is limited to the role of the ministry in public worship, preaching, and the Lord's Supper.

The purpose of public worship is to bless the congregation of God's people. According to Owen, the Christian ministry was the primary instrument through which this blessing is conveyed from God to the saints. ${ }^{170}$ The ministerial office is benedictory, and ministers bless the congregation by administering public ordinances. ${ }^{171}$ This means that ministers are instruments of divine blessing and not causes of them. The reason why he placed emphasis on the Christian ministry in

167 Owen, Hebrews, Works, 18: 5-9.

168 Owen, Theologoumena Pantodapa, lib. VI, cap. 7, 501; A Discourse Concerning Liturgies and their Imposition, Works, 15: 9.

169 Owen, 'Nature and Beauty of Public Worship,' Works, 9: 57.

170 Owen, 'The Duty of a Pastor,' Works, 9: 456-457.

171 Owen treats the nature of benedictions in relation to the ministerial office in Hebrews in Works, 22: 316-320, 368-375. He argued that ministers are benedictory to the congregation by faithfully exercising the duties of their office in obedience to Christ. See McGraw, 'A Heavenly Directory,' chapter 6. 
connection to public worship was because of the common Reformed principle that God appointed ordained ministers alone to administer the ordinances of worship. ${ }^{172}$

The function of the ministry in public worship means that the primary task of ministers is to preach the word of God. ${ }^{173}$ The passage already cited above from the Hebrews commentary regarding the appropriate works of the Father illustrates how this ordinance relates to communion with the Divine Persons. There Owen argued that the Father is the origin of all divine revelation, including the application of that revelation through preaching. ${ }^{174}$ The Father commits His self-revelation to the Son and communicates it only through the Son, whether through the prophets of the Old Testament or the ministers of the word of the New Testament. ${ }^{175}$ The Spirit then applies this revelation to the elect to make it effectual for salvation, both for preachers and for hearers. ${ }^{176}$ Note again the parallel between Owen's treatment of preaching and his exposition of the Reformed doctrine of the knowledge of God. Preaching is the primary means by which God brings His people to the knowledge of Himself through Christ. ${ }^{177}$

The sacraments are a corollary to and concomitant of the word of God. ${ }^{178}$ They have no independent efficacy apart from the preaching of the word. ${ }^{179}$ This means that the sacraments aim at the same kind of trinitarian communion as does preaching. Owen wrote very little about baptism, ${ }^{180}$ but he argued that believers held greater communion with God in the Lord's Supper than in any other ordinance. ${ }^{181}$ This was partly due to the promise of the spiritual presence of Christ in the sacrament and partly due to the fact that this was one of the few ordinances that appealed to the

172 For example, Wollebius, Compendium, 159-160; Leigh, Body of Divinity, 461-466.

173 See Leigh, Body of Divinity, 461-466, who treats the nature and ends of preaching at length as the primary calling of pastors. This is the burden of Owen's sermon on 'The Duty of Pastors' in Works, 9, as cited above (see esp. Works, 9: 453).

174 Owen, Hebrews, Works, 20: 34-35.

175 Owen, A Discourse on Spiritual Gifts; Works, 4: 491.

176 Owen, A Discourse on Spiritual Gifts; Works, 4: 438.

177 Andreas Hyperius, The Practice of Preaching, Otherwise Called the Pathway to the Pulpit, trans. John Ludham (London, 1577), 9; Oliver Bowles, De Pastore Evangelio Tractatus (London, 1659), 2.

178 Wollebius, Compendium, 124.

179 Leigh, Body of Divinity, 655-657.

180 He included scattered references to baptism throughout his Works and a few very short treatments of infant baptism, but he did not devote an extended exposition to this sacrament in any place. For a treatment of his arguments for infant baptism, see Lee Gatiss, 'From Life's First Cry: John Owen on Infant Baptism and Infant Salvation,' in The Ashgate Research Companion, 271-282.

181 Owen, 'The Chamber of Imagery,' Works, 8: 560: 'The communication of Christ herein, and our participation in Him, are expressed in such a manner as to demonstrate them to be peculiar - such as are not to be obtained in any other way or divine ordinance whatever; not in praying, not in preaching, not in any other exercise of faith on the word of promises.' 
whole person, including sense as well as faith. ${ }^{182}$ Richard Sibbes (1577-1635) made the trinitarian emphasis of the Lord's Supper explicit by treating it as a feast setting forth the love of the Father. Christ is the object of faith in the Supper, yet the Father sent the Son. Christ is then present by the Holy Spirit to the faith of believers. ${ }^{183}$ This matches Owen's teaching closely and in this regard, he did not stand out nor was he unusual. He fit within a Reformed tradition that placed a premium on communion with God through word, sacrament, and prayer.

Owen's treatment of Trinity and Ecclesiology ties together all of the themes treated above in this essay. The purpose of administering ordinances in public worship is to promote the true knowledge of God. The triune God administers these ordinances in the context of the church through ordained ministers of the word. ${ }^{184}$ This experience of God is the apex of new covenant worship and it is the outlet of affections that are renewed by the Holy Spirit.

\section{CONCLUSION}

Owen's distinctive contribution to Reformed orthodox trinitarian theology and the reasons behind the general neglect of the Reformed contribution to trinitarian theology converge. While Owen emphasised communion with the Divine Persons and communion with God in public worship more fully than most of his contemporaries, what they held in common was a commitment to the practical use of the doctrine. This appears to be why this area has been largely overlooked in Owen studies and one reason why contemporary treatments often bypass Reformed authors.

For most scholars of historical theology, the conjunction between Owen's trinitarian theology and public worship is not even a topic of discussion. The two secondary works that treat the connection between his Trinitarianism and worship stress communion with God in private worship rather than through the ordinances of public worship. ${ }^{185}$ Many modern treatments of the Trinity are interested in how the doctrine functions in the entire system of theology. The practical use of the doctrine is ordinarily relegated to mystical contemplation and apophatic theology. ${ }^{186}$

182 In every other case, Owen regarded sight and sense as contrary to faith. See the appendix on Owen's view of images of Christ in my Heavenly Directory.

183 Richard Sibbes, The Complete Works of Richard Sibbes, 7 vols. (Edinburgh: James Nichols, 1862), 4: 329.

184 Contra Petto, with whom Owen otherwise shared much agreement both in covenant theology and ecclesiology. John Martin et al., The Preacher Sent: Or, a Vindication of the Liberty of Publick Preaching, by Some Men Not Ordained; in Answer to Two Books: 1. Jus Divinum Ministerii Evangelici: By the Provincial Assembly of London. 2. Vindicice Ministerii Evangelici. by Mr. John Collings. Published by J. Martin, S. Petto, F. Woodal. (London, 1658).

185 Kay, Trinitarian Spirituality; Letham, 'John Owen's Doctrine of the Trinity and its Significance for Today.'

186 As is the case throughout the Oxford Handbook of the Trinity. 
By contrast, Reformed trinitarian piety reflected Reformed Soteriology. ${ }^{187}$ This is precisely what is missing in most contemporary conversations.

John Owen's teaching on communion with the triune God in public worship represents one avenue that Reformed trinitarian piety could take. His treatment on this subject is comprehensive and profound, covering the scope of most major areas of the system of doctrine. This connection that he made between Trinity and public worship is not all that he had to contribute to trinitarian theology either. ${ }^{188}$ Ironically, the most profound Reformed application and development of trinitarian theology is not found in popular works by English Puritans, but in Latin theological treatises, such as those of Hoornbeeck, Voetius, and Van Mastricht. In order to assess Reformed trinitarian theology in general and Owen in particular, more historical investigation is needed. But scholars will not begin looking unless they believe that there is something worth finding. In order to appreciate what historic Reformed orthodoxy has to offer contemporary trinitarian theology, we must look for a Reformed trinitarian piety that asks Reformed questions and reflects Reformed Soteriology. This will also help place John Owen in proper historical context in order to understand how he was distinctive from other writers and why he is worth studying.

\section{LIST OF REFERENCES}

A'Brakel, Wilhemus. The Christian's Reasonable Service. Edited by Joel R. Beeke. Translated by Bartel Elshout. 4 vols. Grand Rapids: Reformation Heritage Books, 2012.

Ames, William. Medulla S.S. Theologice, in Fine Adjuncta Est Disputatio De Fidei Divince Veritate. Editio Tertia Priori Longe Correctior. Apud Robertum Allottum: Londini, 1629.

Ames, William. A Fresh Suit Against Human Ceremonies in Gods Worship or a Triplication Unto D. Burgesse His Rejoinder for D. Morton, ... (by William Ames.). (S.1.), 1633.

Ball, John. A Treatise of the Covenant of Grace Wherein the Gradual Breakings Out of Gospel Grace from Adam to Christ Are Clearly Discovered, the Differences Betwixt the Old and New Testament Are Laid Open, Divers Errours of Arminians and Others Are Confuted, the Nature of Uprightnesse, and the Way of Christ in Bringing the Soul into Communion with Himself ... Are Solidly Handled. London: Printed by G. Miller for Edward Brewster, 1645.

Beach, J. Mark. Christ and the Covenant: Francis Turretin's Federal Theology as a Defense of the Doctrine of Grace. Göttingen: Vandenhoeck \& Ruprecht, 2007.

Bowles, Oliver. 'De Pastore Evangelico Tractatus: In Quo Universum Munus Pastorale; Tam Quoad Pastoris Vocationem, \& Præparationem; Quàm Ipsius Muneris Exercitium: Accuratè Proponitur. Operâ Et Studio Oliveri Bowles Angli, Ecclesiæ Quæ Suttoniæ Est, in Agro Bedfordiensi, Nuper Pastoris Eximii: Et in Synodo Westmonasterii Nuper Convocatâ

187 Wisse and Meijer make a similar observation in relation to pneumatology and Soteriology. Wisse and Meijer, 'Pneumatology: Tradition and Renewal,' Ashgate Research Companion, 500-505.

188 See Trueman, The Claims of Truth, for the Trinity in relation to overarching content of Owen's theology. 
Egregii Theologi.,' 1649. http:/gateway.proquest.com/openurl?ctx_ver=Z39.88-2003\&res_ $\mathrm{id}=$ xri:eebo\&rft_val fmt=\&rft id=xri:eebo:image: 118454 .

Brown, Michael. Christ and the Condition: The Covenant Theology of Samuel Petto (1624-1711). Grand Rapids, Michigan: Reformation Heritage Books, 2012.

Bruce L. McCormack. 'Union with Christ in Calvin's Theology: Grounds for a Divinization Theory?' In Tributes to John Calvin: A Celebration of His Quincentenary, edited by David W. Hall, 504-29. Phillipsburg, N.J.: P \& R Publishing, 2010.

Burroughs, Jeremiah. Gospel-Worship, Or, the Right Manner of Sanctifying the Name of God in General and Particularly in These Three Great Ordinances, Viz. 1. Hearing of the Word, 2. Receiving the Lords Supper, 3. Prayer. London: Printed by Peter Cole, 1658.

Byfield, Richard. The Gospels Glory, Without Prejudice to the Law Shining Forth in the Glory of God [brace] the Father, the Sonne, the Holy Ghost, for the Salvation of Sinners, Who Through Grace Do Believe According to the Draught of the Apostle Paul in Rom. 8.ver. 3.4. Held Out to Publick View. London: Printed by E.M. for Adoniram Byfield at the three Bibles in Corn-hil, next door to Popes-head Alley., 1659.

Charnock, Stephen. Discourses Upon the Existence and Attributes of God. 2 Vols. [S.1.]: Baker Book House, 1853.

Cheynell, Francis. The Divine Trinunity of the Father, Son, and Holy Spirit, Or, the Blessed Doctrine of the Three Coessentiall Subsistents in the Eternall Godhead Without Any Confusion or Division of the Distinct Subsistences or Multiplication of the Most Single and Entire Godhead Acknowledged, Beleeved, Adored by Christians, in Opposition to Pagans, Jewes, Mahumetans, Blasphemous and Antichristian Hereticks, Who Say They Are Christians, but Are Not. London: Printed by T.R. and E.M. for Samuel Gellibrand ..., 1650.

Clarkson, David. The Works of David Clarkson. Edinburgh: Banner of Truth Trust, 1988.

Cooper, Tim. John Owen, Richard Baxter, and the Formation of Nonconformity. Farnham, Surrey, England; Burlington, VT: Ashgate, 2011.

Dickson, David. A Brief Explication of the First Fifty Psalms. London: Printed by T.M. for Thomas Johnson, 1655.

Dickson, David and James Durham. The Summe of Saving Knowledge with the Practical Use Thereof. Edinburgh: Printed by George Swintoun and Thomas Brown and are to be sold by James Glen and $\mathrm{Da}[\mathrm{vid}]$ Trench, 1671.

Edwards, Jonathan. The Works of Jonathan Edwards. Edited by Sereno E Dwight and Edward Hickman. Edinburgh: Banner of Thrust, 1997.

Edwards, Jonathan. The Works of Jonathan Edwards. Edited by Perry Miller, John E Smith, and Harry S Stout. New Haven, Conn., [etc.]; London: Yale University Press ; Oxford University Press, 2008.

Ellis, Brannon. Calvin, Classical Trinitarianism, and the Aseity of the Son. Oxford: Oxford University Press, 2012.

Emery, Gilles and Matthew Levering, eds. The Oxford Handbook of the Trinity. Oxford; New York: Oxford University Press, 2011.

Fesko, John V. 'The Doctrine of Scripture in Reformed Orthodoxy.' In A Companion to Reformed Orthodoxy, edited by H. J. Selderhuis, 40: 429-64. Brill's Companions to the Christian Tradition. Leiden: Brill, 2013. 
Gillespie, George. A Dispute Against the English Popish Ceremonies Obtruded on the Church of Scotland: Wherein Not Only Our Own Arguments Against the Same Are Strongly Confirmed, but Likewise the Answers and Defences of Our Opposites, Such as Hooker, Morton, Burges, Sprint, Paybody, Andrews, Saravia, Tilen, Spotswood, Lindsey, Forbes, Etc., Particularly Confuted. Edited by Christopher Coldwell. Dallas, TX: Naphtali Press, 1993.

Gillespie, Patrick. The Ark of the Covenant Opened, Or, a Treatise of the Covenant of Redemption Between God and Christ, as the Foundation of the Covenant of Grace the Second Part, Wherein Is Proved, That There Is Such a Covenant, the Necessity of It, the Nature, Properties, Parties Thereof, the Tenor, Articles, Subject-Matter of Redemption, the Commands, Conditions, and Promises Annexed, the Harmony of the Covenant of Reconciliation Made with Sinners, Wherein They Agree, Wherein They Differ, Grounds of Comfort from the Covenant of Suretiship. London: Printed for Thomas Pankhurst, 1677.

Ha, Polly and Patrick Collinson, eds. The Reception of Continental Reformation in Britain. Oxford University Press for the British Academy, 2010.

Haykin, Michael A.G. and Mark Jones, eds. Drawn into Controversie: Reformed Theological Diversity and Debates Within Seventeenth-Century British Puritanism. Vol. 17. Reformed Historical Theology. Göttingen: Vandenhoeck \& Ruprecht, 2011.

Hoornbeeck, Johannes. Theologia Practica Pars 1. 2 vols. Francofurti \& Lipsiae: Bailliar, 1698.

Hyperius, Andreas. De Formandis Concionibus Sacris, Seu De Interpretatione Scriptuarum Populari: Libri 2. Marpurgum: Colibius, 1562.

'John Owen's Doctrine of the Trinity and Its Significance Today.' In Where Reason Fails: Papers Read at the 2006 Westminster Conference, 10-22. Westminster Conference, 2006.

Jones, Mark. Antinomianism: Reformed Theology's Unwelcome Guest?, 2013.

Kapic, Kelly M. Communion with God: The Divine and the Human in the Theology of John Owen. Grand Rapids, Mich.: Baker Academic, 2007.

Kapic, Kelly M. and Mark Jones, eds. The Ashgate Research Companion to John Owen's Theology. Farnham, Surrey, England; Burlington, VT: Ashgate, 2012.

Kay, Brian. Trinitarian Spirituality: John Owen and the Doctrine of God in Western Devotion. Bletchley, Milton Keynes, UK; Waynesboro, GA: Paternoster, 2007.

Knapp, Henry M. 'Understanding the Mind of God: John Owen and Seventeenth-Century Exegetical Methodology,' 2002.

Lee, Brian J. Johannes. Cocceius and the Exegetical Roots of Federal Theology. Reformed Historical Theology. Göttingen: Vandenhoeck \& Ruprecht, 2008.

Letham, Robert. The Holy Trinity: In Scripture, History, Theology, and Worship. Phillipsburg, NJ: P \& R Pub., 2004.

Lim, Paul Chang-Ha. Mystery Unveiled: The Crisis of the Trinity in Early Modern England. New York: Oxford University Press, 2012.

Matthews, A.G. The Savoy Declaration of Faith and Order, 1658. London: Independent Press, 1959.

Martin, John, Samuel Petto, Fredrick Woodall and John Collinges. The Preacher Sent: Or, a Vindication of the Liberty of Publick Preaching, by Some Men Not Ordained; in Answer to Two Books: 1. Jus Divinum Ministerii Evangelici: By the Provincial Assembly of London. 
2. Vindicice Ministerii Evangelici. by Mr. John Collings. Published by J. Martin, S. Petto, F. Woodal. London, 1658.

McGraw, Ryan M. 'A Review of Michael Brown, Christ and the Condition: The Covenant Theology of Samuel Petto (1624-1711).' Mid-America Journal of Theology 23 (2012): 15255.

Muller, Richard A. Post-Reformation Reformed Dogmatics: The Rise and Development of Reformed Orthodoxy, Ca. 1520 to Ca. 1725. 2nd ed. 4 vols. Grand Rapids, MI: Baker Academic, 2003.

Muller, Richard A. 'Toward the Pactum Salutis: Locating the Origins of a Concept.' Mid-America Journal of Theology 18 (2007): 11-65.

Muller, Richard A. Christ and the Decree: Christology and Predestination in Reformed Theology from Calvin to Perkins. Grand Rapids, Mich.: Baker Academic, 2008.

Neele, Adriaan C. Petrus van Mastricht (1630-1706) Reformed Orthodoxy: Method and Piety. Leiden; Boston: Brill, 2009.

Owen, John. Theologoumena Pantodapa, Sive, De Natura, Ortu Progressu, Et Studio Verce Theologice, Libri Sex Quibus Etiam Origines \& Processus Veri \& Falsi Cultus Religiosi, Casus \& Instaurationes Ecclesice Illustiores Ab Ipsis Rerum Primordiis, Enarrantur. Oxoniæ: Excudebat Hen. Hall, impensis Tho. Robinson, 1661.

Owen, John. The Works of John Owen, D.D. Edited by William H. Goold. 24 vols. Edinburgh: Johnstone \& Hunter, 1850.

Perkins, William. A Warning Against the Idolatrie of the Last Times and an Instruction Touching Religious, or Diuine Worship. [Cambridge]: Printed by Iohn Legat, printer to the Vniuersitie of Cambridge. And are to be sold at the sign of the Crown in Pauls Churchyard [London], by Simon Waterson, 1601.

Petto, Samuel. The Difference Between the Old and New Covenant Stated and Explained with an Exposition of the Covenant of Grace in the Principal Concernments of It. London: Printed for Eliz. Calvert ..., 1674.

Phan, Peter C. The Cambridge Companion to the Trinity. Cambridge; New York: Cambridge University Press, 2011.

Rehnman, Sebastian. Divine Discourse: The Theological Methodology of John Owen. Grand Rapids: Baker Academic, 2002.

Reynolds, Edward. The Works of ... Edward Reynolds ... Containing Three Treatises of the Vanity of the Creature. the Sinfulness of Sin. the Life of Christ ... with a Collection of Thirty Sermons Preached on Several Solemn Occasions ... [London] In the Savoy: Printed by Tho. Newcomb, and are to be sold by Robert Boulter, 1679.

Sibbes, Richard. The Complete Works of Richard Sibbes. 7 vols. Edinburgh: James Nichols, 1862.

Trueman, Carl R. The Claims of Truth: John Owen's Trinitarian Theology. Carlisle, Cumbria: Paternoster Press, 1998.

Trueman, Carl R. John Owen: Reformed Catholic, Renaissance Man. Aldershot, England; Burlington, Vt.: Ashgate, 2007.

Tyacke, Nicholas. Anti-Calvinists: The Rise of English Arminianism, C. 1590-1640. Oxford [Oxfordshire]; New York: Clarendon Press ; Oxford University Press, 1987. 
Van Asselt, W. J. The Federal Theology of Johannes Cocceius (1603-1669). Leiden; Boston: Brill, 2001 .

Van Mastricht, Peter. Theoretico-Practica Theologia. Qua, Per Singula Capita Theologica, Pars Exegetica, Dogmatica, Elenchtica \& Practica, Perpetua Successione Conjugantur. Trajecti ad Rhenum, \& Amstelodami: Sumptibus Societatis, 1715.

Voetius, Gijsbert. Selectarum Disputationum Theologicarum Pars Prima (Quinta. Accedunt Dissertatio Epistolica De Termino Vitee. Exercitatio De Prognosticis Cometarum. Antehac Seorsim Editce). 5 vols. Ultrajecti, 1648.

Westminster Assembly. A Directory for the Publique Worship of God Throughout the Three Kingdoms of England, Scotland, and Ireland Together with an Ordinance of Parliament for the Taking Away of the Book of Common-Prayer: And for Establishing and Observing of This Present Directory Throughout the Kingdom of England and Dominion of Wales ... London: Printed by M.B. and A.M. for the Company of Stationers, 1646.

Witsius, Herman. De Oeconomia Foederum Dei Cum Hominibus Libri Quatuor. 2 vols. Trajecti ad Rhenum: apud Franciscum Halmam, Gulielmum van de Water, 1694.

Witsius, Herman. On the Character of a True Theologian. Greenville, S.C.: Reformed Academic Press, 1994.

Wollebius, Johannes. Compendium Theologice Christiance, Editio Ultima Prioribus Multo Correctior. 9th ed. Cantabrigiæ, 1655. 